OPEN ACCESS

Edited by:

María Del Mar Guerrero, Instituto Murciano de Investigación y

Desarrollo Agrario y Alimentario (IMIDA), Spain

Reviewed by:

Mahadevakumar Shivannegowda, University of Mysore, India

Amisha Poret-Peterson,

Agricultural Research Service,

United States Department of Agriculture (USDA), United States

*Correspondence: David M. Butler dbutler@utk.edu

Specialty section:

This article was submitted to Waste Management in

Agroecosystems,

a section of the journal

Frontiers in Sustainable Food Systems

Received: 25 July 2021 Accepted: 18 October 2021 Published: 12 November 2021

Citation:

Swilling KJ, Shrestha $U$, Ownley $B H$, Gwinn KD and Butler DM (2021)

Mechanisms of Anaerobic Soil

Disinfestation: Volatile Fatty Acids Reduce Viability of Athelia (Sclerotium)

rolfsii Sclerotia in Acidic Soll

Conditions and Have Limited Effects on Endemic Trichoderma spp. Front. Sustain. Food Syst. 5:747176. doi: 10.3389/fsufs. 2021.747176

\section{Mechanisms of Anaerobic Soil Disinfestation: Volatile Fatty Acids Reduce Viability of Athelia (Sclerotium) rolfsii Sclerotia in Acidic Soil Conditions and Have Limited Effects on Endemic Trichoderma spp.}

\author{
Keagan J. Swilling ${ }^{1}$, Utsala Shrestha ${ }^{1}$, Bonnie H. Ownley ${ }^{2}$, Kimberly D. Gwinn ${ }^{2}$ and \\ David M. Butler ${ }^{1 *}$
}

${ }^{1}$ Department of Plant Sciences, University of Tennessee, Knoxville, TN, United States, ${ }^{2}$ Department of Entomology and Plant Pathology, University of Tennessee, Knoxville, TN, United States

Volatile fatty acids (VFAs), such as acetic and $n$-butyric acid, released during anaerobic decomposition of organic soil amendments during anaerobic soil disinfestation (ASD) likely play a role in soilborne plant pathogen inoculum suppression. However, research is limited on the direct effects of soil VFA exposure on fungal plant pathogen inoculum, effects on pathogen antagonists such as Trichoderma spp., and the role of soil microbial VFA metabolism on reducing exposure effects. The present study addresses these limitations through a series of studies evaluating the effects of VFA (acetic or $n$-butyric acid), VFA concentration (4, 8, or $16 \mathrm{mmol} / \mathrm{kg}$ soil), soil sterilization by autoclaving, and soil amendment on the viability of Athelia rolfsii (Sclerotium rolfsii) sclerotia post VFA exposure, and soil populations of Trichoderma spp. $\mathrm{HCl}$ and water-only controls were included. After 4-days exposure in an acidic, anaerobic environment, sclerotial viability, and colonization by culturable fungi or bacteria were assessed with standard procedures. Greenhouse experiments were similarly conducted to evaluate endemic soil populations of Trichoderma spp. following soil exposure to VFAs and Trichoderma spp. populations assessed with standard soil dilution plating onto semi-selective medium. Sclerotial germination was generally reduced by soil exposure to acetic (35.1\% germination) or n-butyric (21.9\% germination) acids compared to water (74.3\% germination) and $\mathrm{HCl}$ (62.7\% germination). Germination was reduced as VFA concentration increased from 4 to 8 and $16 \mathrm{mmol} / \mathrm{kg}(39.5,29.1$, and $16.9 \%$, respectively). In amended soils, there was no difference in sclerotial germination compared to non-amended soils, but in the greenhouse experiment there was a Trichoderma spp. population increase of over $300 \%$ in amended soil [3.4 $\times 10^{6}$ colony forming units (CFU)/g soil] compared to the non-amended soil $\left(9.6 \times 10^{5} \mathrm{CFU} / \mathrm{g}\right.$ soil). Soil autoclaving had no effect on sclerotial germination at low VFA concentrations, but sclerotial germination was reduced at higher VFA concentrations compared to non-autoclaved soil. Our results suggest that VFAs 
contribute to sclerotial mortality in strongly acidic soil environments, and mortality is influenced by VFA components and environment. Antifungal activity is less for acetic acid than for $n$-butyric, and less in non-sterile soil environments more typical of field conditions than in sterile laboratory conditions.

Keywords: biological soil disinfestation, organic acids, organic amendment, biological control, soilborne fungal plant pathogens, southern blight

\section{INTRODUCTION}

Biological or anaerobic soil disinfestation (ASD) is a feasible alternative to soil fumigation for soilborne plant pathogen inoculum control in several environments and cropping systems (Butler et al., 2014; Shennan et al., 2014; Rosskopf et al., 2015; Shrestha et al., 2016), but specific control mechanisms are not well-described across environments and pathosystems. Numerous changes to soil chemical, physical, and biological properties likely contribute to ASD treatment effects (Runia et al., 2014; Hewavitharana et al., 2015; Rosskopf et al., 2015; Hewavitharana and Mazzola, 2016; Shrestha et al., 2021). Volatile fatty acids (VFAs), including acetic acid, $n$-butyric acid, isobutyric acid, valeric acid, and isovaleric acid, are present in varying rates in biologically active moist soils, but are formed at high rates during the anaerobic decomposition of labile organic amendments during ASD and can create strongly acidic soil conditions for a brief time (Blok et al., 2000; Momma et al., 2006; Runia et al., 2014). The VFAs are then readily metabolized by aerobic microbes during soil oxidation that would follow ASD treatment (Adeleke et al., 2017). There are multiple reports that ASD treatment induces relatively high soil concentrations of acetic and $n$-butyric acid (Momma et al., 2006; Runia et al., 2014; Huang et al., 2015; Shrestha et al., 2020a). These compounds are likely an important factor in control of inoculum of some soilborne fungal plant pathogens, including Fusarium oxysporum and Verticillium dahliae, and plant parasitic nematodes such as Pratylenchus penetrans and Pyrenochaeta terrestris (Blok et al., 2000; Shinmura, 2004; Browning et al., 2006; Momma et al., 2006; Oka, 2010; Runia et al., 2014; Huang et al., 2015), but it is unclear how VFAs and carbon amendments affect viability of large fungal sclerotia (like those of Athelia rolfsii) or potential mycoparasites of sclerotia-forming plant pathogens, such as Trichoderma or Mucor spp., during ASD treatment in field (i.e., non-autoclaved) soils.

Studies by Tenuta et al. (2002) and Abbasi et al. (2009) indicated that VFAs reduced numbers of microsclerotia of $V$. dahliae after several days, and the effect was more pronounced at lower soil pH. Similarly, Swilling et al. (2021) reported that soil $\mathrm{pH}$ and soil texture affected the antifungal activity of VFAs against $A$. rolfsii in autoclaved soils under laboratory conditions. The $\mathrm{pKa}$ values for both acetic and $n$-butyric acids are near 4.8 so in an acidic soil, a larger ratio of the VFAs would be in a non-dissociated state. Non-dissociated forms are generally more toxic to soilborne plant pathogens because in the undissociated state the compounds likely more able to readily diffuse across cell membranes, thereby leading to cytoplasm acidification (Browning et al., 2006; Runia et al., 2014). It follows that because VFAs suppress soilborne plant pathogens (such as $A$. rolfsii), that VFAs may also affect other organisms present in the soil such as the fungal mycoparasite, Trichoderma.

Athelia rolfsii (Sclerotium rolfsii) is an economically-damaging fungal plant pathogen that causes southern blight in a wide range of host plants including tomato, pepper, and many other vegetable and legume crops (Mullen, 2001). Southern blight disease symptoms typically form initially at the base of the plant and spread toward the roots, but the pathogen can also infect leaves and fruits in contact with soil. Athelia rolfsii occurs in tropical to subtropical regions globally, preferring warm moist soils and temperatures over $25^{\circ} \mathrm{C}$, however, it can grow at temperatures as low as $8^{\circ} \mathrm{C}$ (Punja, 1985; Mullen, 2001). Long term survival structures (sclerotia) are formed when mycelium condenses to form a protective, melanized rind. Sclerotia can remain dormant in soil for multiple years and are easily dispersed with soil movement (Punja, 1985; Xu, 2008).

The genus, Trichoderma, contains numerous species commonly found in soils, especially those rich in root systems. Selected isolates of Trichoderma, particularly T. harzianum, are effective biocontrol agents for soilborne plant pathogens including Fusarium, Phytophthora, and A. rolfsii (Mishra et al., 2011). Trichoderma species have also been linked to promotion of plant growth and drought resistance in plants (Duffy et al., 1997; Yedidia et al., 2001; Benítez et al., 2004). As a biocontrol, Trichoderma spp. use several mechanisms to slow down or inhibit the growth of plant pathogens. Trichoderma spp. can directly parasitize and lyse the mycelia of other fungi and nematode integuments through enzymes (Chet et al., 1981; Sharon et al., 2001) and produces antibiotics that negatively affect other soilborne organisms (Mishra et al., 2011). Trichoderma species typically grow rapidly and can displace other fungi in the soil environment (Benítez et al., 2004). Bulluck and Ristaino (2002) observed that Trichoderma suppressed A. rolfsii and that Trichoderma populations were enhanced by addition of organic amendments. Shrestha et al. (2018) similarly observed Trichoderma parasitizing A. rolfsii post ASD treatment, at percentages higher than observed for nonamended controls. It follows that populations of Trichoderma spp. may be an important consideration in evaluation of non-chemical and biological techniques of soil disinfestation. Similarly, Mucor spp. have been observed colonizing sclerotia post ASD treatment (Shrestha et al., 2018) and Mucor spp. have been reported as probable mycoparasites of sclerotia of Sclerotinia sclerotiorum (Merriman, 1976; Adams and Ayers, 1979; Harvey et al., 1995). Increased mechanistic understanding 
of ASD treatment and effects on these potential mycoparasites colonizing sclerotia will facilitate development of treatment recommendations for effective use of biologically-based ASD treatment.

Based on preliminary data and previous studies, our objectives were as follows: (1) evaluate effect of ASD amendment and soil autoclaving on sclerotial colonization and VFA-induced suppression of germination of $A$. rolfsii sclerotia during ASD, and (2) evaluate impact of acetic and $n$-butyric acids and organic soil amendment during ASD on Trichoderma spp. population dynamics post ASD treatment. We hypothesized that: (1) VFA exposure will reduce A. rolfsii germination in a VFA concentration dependent manner, and that soil microbial activity in non-autoclaved soil and organic amendments used during ASD will alter the effect of VFAs on A. rolfsii germination, and (2) acetic and $n$-butyric acids will increase soil Trichoderma spp. populations as a function of VFA concentration and organic amendment.

\section{MATERIALS AND METHODS}

\section{Experiment 1, Role of Soil Autoclaving and ASD Amendment on VFA-Induced Suppression of $A$. rolfsii}

To evaluate the effect of endemic soil microbial activity and ASD amendment on VFA-induced suppression of A. rolfsii germination, the activity of VFAs in field soils that were either autoclaved ( $45 \mathrm{~min}$ at $121^{\circ} \mathrm{C}$ and $103 \mathrm{kPa}$, twice, $24 \mathrm{~h}$ apart) or not autoclaved, and amended with an organic amendment or not amended were evaluated. Based on the work of Shrestha et al. (2018), the organic amendment was a mixture of dry molasses on a soy hull carrier and corn starch at a rate of $4 \mathrm{mg}$ $\mathrm{C} / \mathrm{g}$ soil, with a carbon to nitrogen ratio of 30:1. The study was a completely randomized factorial design with two levels of soil autoclaving (autoclaved, non-autoclaved), two ASD organic amendment treatments (amended, non-amended), two VFAs (acetic, $n$-butyric acids), and three VFA concentrations $(4,8$, and $16 \mathrm{mmol} / \mathrm{kg}$ soil at a single soil $\mathrm{pH}$ of 5.0). $\mathrm{HCl}$ was used as an acid control at a soil $\mathrm{pH}$ of 5.0 and $16 \mathrm{mmol} / \mathrm{kg}$ soil concentration, and sterile water was used as a baseline control. There were four replicates in each of two repeated trials of the study. The soil was air-dried field soil from the surface horizon at the University of Tennessee Organic Crops Unit, Knoxville, TN, USA (Dewey silt loam, fine, kaolinitic, and thermic typic Paleudult) mixed in equal parts with sand (particle size range from 0.0625 to $1.5 \mathrm{~mm}$ ) by volume, this resulted in a sandy loam soil texture with a clay content of $10 \%$.

Concentrations of VFA were selected based on previous studies $(4,8$, and $16 \mathrm{mmol} / \mathrm{kg}$ soil) to represent a typical range of the VFA concentrations present in soil during the ASD process (e.g., Shrestha et al., 2020a). Working solutions were created by combining reagent-grade concentrated VFA with autoclaved double deionized water to achieve concentrations of $0.027,0.053$, and $0.107 \mathrm{M}$. These concentrations were equivalent to final soil concentrations of 4,8 , and $16 \mathrm{mmol} / \mathrm{kg}$ dry soil given treatment application rates. Stock solution $\mathrm{pH}$ was determined using a
$\mathrm{pH}$ electrode (Orion Star A221, Thermo Scientific, Waltham, MA, USA). To determine soil solution $\mathrm{pH}, 750 \mu \mathrm{L}$ of VFA solution was added to $5 \mathrm{~g}$ soil. After a $10 \mathrm{~min}$ equilibration, soil $\mathrm{pH}$ was measured using a $\mathrm{pH}$ electrode in soil mixed with $10 \mathrm{~mL}$ of $0.01 \mathrm{M} \mathrm{CaCl}_{2}$ (Kissel et al., 2009). To achieve the desired $\mathrm{pH}$ value, based on soil buffering, $\mathrm{Ca}(\mathrm{OH})_{2}$ or $1.2 \mathrm{M}$ $\mathrm{HCl}$ solution was added to VFA solutions in small quantities while $\mathrm{pH}$ was monitored with a submerged $\mathrm{pH}$ electrode. Final soil $\mathrm{pH}$ of the VFA and soil mixture measured in $0.01 \mathrm{M} \mathrm{CaCl}_{2}$ was 4.5, and was 5.0 when measured in water (as expected when comparing $\mathrm{pH}$ measurements in water vs. $0.01 \mathrm{M} \mathrm{CaCl}_{2}$ ) (Kissel et al., 2009).

Sclerotia of $A$. rolfsii were cultured from an isolate originally isolated from hybrid field tomatoes at the East Tennessee Research and Education Center, Knoxville, TN, USA cultured at room temperature $\left(21^{\circ} \mathrm{C}\right.$ ) on pepper (Capsicum annuum, cv. Felicity F1) leaf and stem tissue. Briefly, frozen pepper tissue was chopped $(<2.5 \mathrm{~cm})$ and placed into 1-L Erlenmeyer flasks corked with Poly-fil and cheesecloth and covered with aluminum foil. Plant tissue was autoclaved twice with 24-h between sterilizations. After the second autoclave cycle, flasks were cooled to room temperature and ten sclerotia of A. rolfsii were added to each flask. Flasks were incubated for 3-4 weeks until large numbers of sclerotia were produced. Sclerotia were harvested under a biosafety cabinet and left in an open Petri dish in the cabinet to dry overnight. Sclerotia were stored at $8^{\circ} \mathrm{C}$ in Petri dishes sealed with Parafilm until needed. Using this method, with $300-\mathrm{cm}^{3}$ pepper tissue (autoclaved volume), $\sim 1,000$ sclerotia were produced per flask.

To evaluate sclerotial germination after exposure to VFAs, $10 \mathrm{~g}$ of soil and 10 sclerotia each were added to autoclaved $20-\mathrm{mL}$ glass scintillation vials and mixed with light shaking. Treatments were randomly assigned, and $1.5 \mathrm{~mL}$ of solution (acetic acid, $n$-butyric acid, $\mathrm{HCl}$, or water) was added to each vial of soil to bring the $10 \mathrm{~g}$ of soil to the water-holding capacity of the soil mixture (without standing water in the vials). Vials were then lightly shaken to ensure that all areas of the soil were thoroughly moistened by the solution. Lidded vials were placed into a controlled atmosphere chamber (Model 855-AC, PLAS LABS, Lansing, MI, USA) with an atmosphere of $90 \% \mathrm{~N}_{2}, 5 \%$ $\mathrm{CO}_{2}$, and $5 \% \mathrm{H}_{2}$ and lids were removed for $5 \mathrm{~min}$ while the palladium molecular sieve of the anaerobic chamber removed existing oxygen from the chamber and vials. Vials were then relidded and then incubated in the anaerobic chamber at room temperature for 4 days. A 4-day period was selected based on the cycles of VFA concentrations seen in previous ASD field experiments (Shrestha et al., unpublished data). After the 4day period, vials were removed from the chamber, and sclerotia plated individually into 24-well-plates with $32 \mathrm{~g} / \mathrm{L}$ PDA with 6.9 $\mathrm{mg} / \mathrm{L}$ fenpropathrin (Sigma-Aldrich, St. Louis, MO, USA) and incubated at room temperature. Germination of sclerotia (yes, no) was observed and recorded over the 1-week period after plating, and colonization of sclerotia (yes, no) by Trichoderma spp., Mucor spp., Bacillus spp., or other uncharacterized fungi or bacteria was recorded at 3 days after plating. Percentage germination or colonization of the 10 sclerotia in each vial was calculated for each replicate vial. 


\section{Experiment 2, Response of Endemic Soil Populations of Trichoderma spp. to VFA, VFA Concentration, and ASD Soil Amendment}

To evaluate Trichoderma spp. population post ASD treatment, $20-\mathrm{cm}$ plastic pots were filled with $1.3 \mathrm{~kg}$ sandy loam soil (50:50 mixture of sand and field soil from the University of Tennessee Organic Crops Unit, Knoxville, TN, USA). The experiment was established as a randomized complete block design with four replicates per trial, which was repeated. Treatments included a factorial combination of two VFAs (acetic, $n$-butyric), three VFA concentrations (4, 8 , and $16 \mathrm{mmol} / \mathrm{kg}$ soil), and two ASD organic amendment treatments (amended, non-amended). The organic amendment was a mixture of dry molasses, soyhulls, and corn starch at a rate of $4 \mathrm{mg} \mathrm{C} / \mathrm{g}$ soil and a carbon to nitrogen ratio of 30:1 as in experiment 1. Control treatments included sterile water and $\mathrm{HCl}$ at $16 \mathrm{mmol} / \mathrm{kg}$ soil as described in experiment 1 , factorially combined with both amended and unamended treatments. Following organic amendment incorporation into the soil mixture, $300 \mathrm{~mL}$ of VFA (or water or $\mathrm{HCl}$ for controls) solution was applied to each pot and the pot surface was sealed using polyethylene mulch secured on each pot with heavyduty rubber bands. The pots were incubated for 3 weeks in a greenhouse $\left(13-18^{\circ} \mathrm{C}\right.$ at night and $21-27^{\circ} \mathrm{C}$ during the day). After 3 weeks, the polyethylene mulch was removed and soil samples $(30 \mathrm{~g})$ were taken from the center of the pot at a depth of $0-3 \mathrm{~cm}$ and stored at $4^{\circ} \mathrm{C}$ until analysis.

To determine the population of Trichoderma spp. in each sample, $1 \mathrm{~g}$ of soil was added to $9 \mathrm{~mL}$ of sterile double deionized water, and serial dilutions from $10^{-1}$ to $10^{-3}$ were prepared. From each dilution, $0.1 \mathrm{~mL}$ was spread onto Trichoderma selective medium (TSM) containing $39 \mathrm{~g} / \mathrm{L}$ PDA amended with $0.02 \mathrm{~g} / \mathrm{L}$ rose bengal, $0.3 \mathrm{~g} / \mathrm{L}$ chloramphenicol, $0.02 \mathrm{~g} / \mathrm{L}$ streptomycin sulfate, prepared at pH 6 (Gil et al., 2009). The plates were covered and incubated in dark storage boxes for 3 days, after which colony forming units (CFUs) of Trichoderma spp. were counted.

\section{Statistical Analysis}

Data were subjected to mixed models analysis of variance using PROC GLIMMix in SAS 9.4 (SAS Institute, Cary, NC, USA). Experiment 1 was a factorial completely randomized design with four factors $(2 \times 2 \times 2 \times 3)$. The main effects and interactions of soil autoclaving (autoclaved, non-autoclaved), ASD organic amendment (amended, non-amended), VFA (acetic, $n$-butyric), and VFA concentration $(4,8$, and $16 \mathrm{mmol} / \mathrm{kg}$ soil) were treated as fixed effects, and repeated trials were treated as random effects. Experiment 2 was a factorial randomized complete block design with three factors $(2 \times 3 \times 2)$. The main effects and interactions of VFA (acetic, $n$-butyric), VFA concentration (4, 8 , and $16 \mathrm{mmol} / \mathrm{kg}$ soil), and ASD amendment (amended, nonamended) were treated as fixed effects and trial and block treated as random effects. Differences between means were determined with an F-protected LSD at $P \leq 0.05$. Rank (Trichoderma spp. populations) or arcsine square root (percentage sclerotia germination and colonization) transformations of data were used to satisfy the non-normal distribution and unequal variances of residual error. Untransformed means and standard error of the mean are reported. Given that controls could not be included in the factorial analysis described previously, controls were analyzed with a separate statistical analysis by comparing to each experimental treatment in the factorial design.

\section{RESULTS}

\section{Experiment 1}

Significant main effects on sclerotial germination were observed for VFA, VFA concentration, and soil autoclaving, but not ASD soil amendment in experiment 1 (Table 1). A significant interaction effect was observed between VFA and soil autoclaving, VFA concentration and soil autoclaving, and ASD soil amendment and soil autoclaving (Table 1).

For the main effect of VFA, in acetic acid treatments, percentage germination of sclerotia averaged $35.1 \%$ compared to $21.9 \%$ for $n$-butyric acid treatments (Table 2). For comparison, sclerotia in the $\mathrm{HCl}$ controls had an average germination of $62.7 \%$, and in water controls germination averaged $74.3 \%$ (averaged across both autoclaved and non-autoclaved soil treatments). For the main effect of VFA concentration, germination of sclerotia in the $4 \mathrm{mmol} / \mathrm{kg}$ treatment averaged $39.5 \%$ compared to the $29.1 \%$ at the $8 \mathrm{mmol} / \mathrm{kg}$ soil treatment and $16.9 \%$ at the $16 \mathrm{mmol} / \mathrm{kg}$ soil treatment, which all differed significantly. In non-control treatments, sclerotial germination averaged $18.1 \%$ for the autoclaved soil which was significantly less than that for the non-autoclaved soil (38.9\% germination; Table 2).

A significant interaction effect between VFA concentration and soil autoclaving was observed, such that at $4 \mathrm{mmol} / \mathrm{kg}$ soil VFA concentration, sclerotial germination did not significantly differ between the autoclaved soil treatments (36.9\%) and the non-autoclaved soil treatments $(42.2 \%)$ when averaged across VFAs (Figure 1). At $8 \mathrm{mmol} / \mathrm{kg}$ soil, autoclaved soil had a lower sclerotial germination (16.6\%) compared with that of the nonautoclaved soil (41.6\%). At $16 \mathrm{mmol} / \mathrm{kg}$ soil concentration, a similar trend was observed with lower sclerotial germination $(0.9 \%)$ in autoclaved soil treatments compared to non-autoclaved soil treatment (32.8\%; Figure 1). Germination of sclerotia in the $\mathrm{HCl}$ and water controls was 50.4 and $64.4 \%$, respectively, in nonautoclaved soil and 75.0 and $84.4 \%$, respectively, in autoclaved soil, an inverse relationship to effects of soil autoclaving in VFA treatments (Figure 1). The interaction of VFA with soil autoclaving resulted in the highest germination observed from acetic acid treatments in non-autoclaved soil (49.8\%), intermediate with acetic acid in autoclaved soil (20.4\%) or $n$ butyric acid in non-autoclaved soil (27.9\%) and the lowest from $n$-butyric acid treatments in autoclaved soil (15.8\% germination; data not shown). Irrespective of ASD soil amendment, sclerotial germination in VFA-amended treatments was higher in nonautoclaved soil (36.4-41.5\%) than in autoclaved soil with (13.5\% germination) or without (22.7\%) ASD soil amendment (data not shown).

Colonization of sclerotia by Trichoderma, Mucor, Bacillus, and other unidentified bacteria was significantly affected by both 
TABLE 1 | Analysis of variance of the response variables percentage germination of Athelia rolfsii sclerotia and percentages colonization of sclerotia by soil fungi and bacteria in experiment 1 as affected by the main effects of volatile fatty acid (VFA) type, VFA concentration, ASD soil amendment, soil autoclaving, and their interactions.

\begin{tabular}{|c|c|c|c|c|c|c|}
\hline & Sclerotial germination & \multicolumn{5}{|c|}{ Sclerotia colonization } \\
\hline & \multicolumn{6}{|c|}{$P$-value } \\
\hline VFA & $<0.001$ & $<0.001$ & $<0.001$ & 0.008 & NS & 0.01 \\
\hline VFA concentration & $<0.001$ & 0.01 & $<0.001$ & NS & NS & $<0.001$ \\
\hline VFA $\times$ soil amendment & NS & 0.02 & 0.05 & NS & NS & NS \\
\hline VFA concentration $\times$ soil amendment & NS & NS & NS & NS & NS & NS \\
\hline VFA $\times$ VFA concentration $\times$ soil amendment & NS & NS & NS & NS & NS & NS \\
\hline Soil autoclaving & $<0.001$ & $<0.001$ & $<0.001$ & 0.003 & $<0.001$ & $<0.001$ \\
\hline VFA $\times$ soil autoclaving & 0.02 & $<0.001$ & NS & 0.003 & NS & NS \\
\hline VFA concentration $\times$ soil amendment $\times$ soil autoclaving & NS & NS & NS & NS & NS & NS \\
\hline VFA $\times$ concentration $\times$ soil amendment $\times$ soil autoclaving & NS & NS & 0.05 & NS & NS & NS \\
\hline
\end{tabular}

NS, not significant, $P>0.05$.

TABLE 2 | Mean percentage germination of Athelia rolfsii sclerotia and percentages colonization of sclerotia in experiment 1 as affected by main effects of volatile fatty acid (VFA) type, VFA concentration, ASD soil amendment, and soil autoclaving.

\begin{tabular}{|c|c|c|c|c|c|c|}
\hline & Sclerotial germination & \multicolumn{5}{|c|}{ Sclerotial colonization } \\
\hline & \multicolumn{6}{|c|}{ Percentage (\%) } \\
\hline \multicolumn{7}{|l|}{ VFA } \\
\hline Acetic & $35.1( \pm 3.3)^{\mathrm{a}}$ & $11.9( \pm 2.5)^{\mathrm{a}}$ & $38.2( \pm 3.9)^{\mathrm{a}}$ & $4.0( \pm 1.3)^{\mathrm{a}}$ & $7.8( \pm 1.2)$ & $7.9( \pm 1.7)^{\mathrm{a}}$ \\
\hline n-butyric & $21.9( \pm 2.8)^{\mathrm{b}}$ & $0.9( \pm 0.8)^{b}$ & $18.0( \pm 3.1)^{b}$ & $0.6( \pm 0.3)^{b}$ & $6.8( \pm 1.6)$ & $4.2( \pm 1.2)^{b}$ \\
\hline 4 mmol/kg soil & $39.5( \pm 3.8)^{\mathrm{a}}$ & $8.4( \pm 2.7)^{a}$ & $35.6( \pm 4.7)^{\mathrm{a}}$ & $3.3( \pm 1.5)$ & $8.3( \pm 1.6)$ & $11.7( \pm 2.6)^{\mathrm{a}}$ \\
\hline 8 mmol/kg soil & $29.1( \pm 3.5)^{b}$ & $8.8( \pm 2.8)^{\mathrm{a}}$ & $32.7( \pm 4.9)^{\mathrm{a}}$ & $2.5( \pm 1.3)$ & $9.1( \pm 2.2)$ & $4.2( \pm 1.4)^{\mathrm{b}}$ \\
\hline $16 \mathrm{mmol} / \mathrm{kg}$ soil & $16.9( \pm 3.5)^{\mathrm{c}}$ & $2.0( \pm 0.9)^{b}$ & $16.1( \pm 3.4)^{b}$ & $1.1( \pm 0.6)$ & $4.5( \pm 1.2)$ & $2.2( \pm 0.9)^{b}$ \\
\hline \multicolumn{7}{|l|}{ Soil amendment } \\
\hline Amended & $27.5( \pm 3.0)$ & $9.5( \pm 2.3)^{a}$ & $36.6( \pm 3.9)^{a}$ & $2.5( \pm 1.0)$ & $8.3( \pm 1.6)$ & $4.7( \pm 1.1)$ \\
\hline Non-amended & $29.5( \pm 3.2)$ & $3.3( \pm 1.3)^{b}$ & $19.7( \pm 3.3)^{b}$ & $2.1( \pm 0.9)$ & $6.3( \pm 1.2)$ & $7.4( \pm 1.8)$ \\
\hline
\end{tabular}

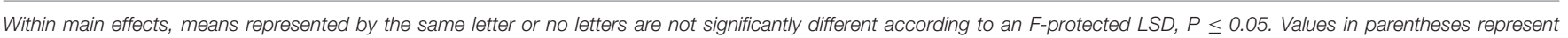
standard error of the mean.

VFA and VFA concentration; colonization by Trichoderma and Mucor was significantly affected by ASD soil amendment; and colonization by all (Trichoderma, Mucor, Bacillus, other fungi and other bacteria) was significantly affected by soil autoclaving (Table 1). There were also numerous significant interaction effects on sclerotial colonization by Trichoderma spp. (Table 1).

Colonization was higher in acetic acid treatments than in $n$-butyric acid treatments for Trichoderma spp. (11.9 vs. $0.9 \%$ colonization, respectively), Mucor spp. (38.2 vs. 18.0\%), Bacillus spp. ( 4.0 vs. $0.6 \%$ ), and other bacteria ( 7.9 vs. $4.2 \%$; Table 2 ). The main effect of VFA concentration showed reduced percentage colonization as VFA concentration increased, with the lowest colonization of Trichoderma spp., Mucor spp., and other bacteria observed at $16 \mathrm{mmol} / \mathrm{kg}$ soil concentration (Table 2). ASD soil amendment increased colonization by Trichoderma spp. (9.5\% colonization vs. $3.3 \%$ in non-amended treatments) and Mucor spp. (36.6 vs. 19.7\%; Table 2). Soil autoclaving effects on colonization varied with organisms; autoclaving reduced 


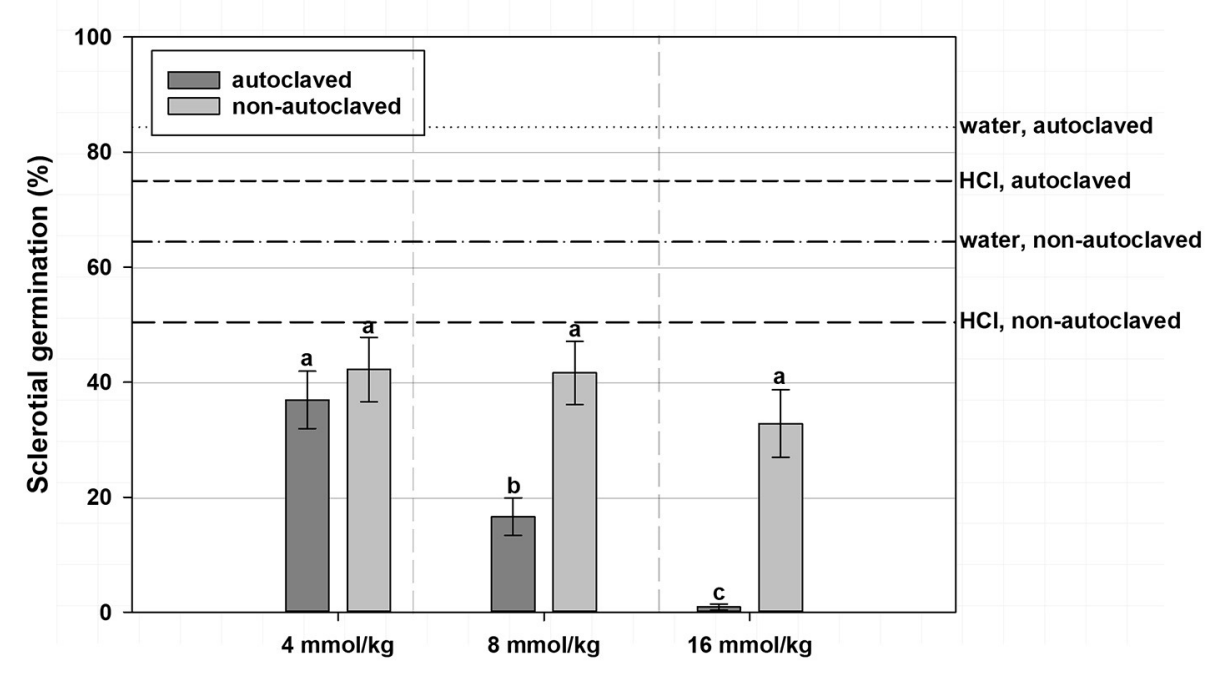

FIGURE 1 | Mean percentage germination of $A$. rolfsii sclerotia in experiment 1 as affected by volatile fatty acid (VFA) concentration, and soil autoclaving. Bars indicated by the same letter are not significantly different according to an F-protected LSD at $P \leq 0.05$. Error bars represent standard error of the mean.

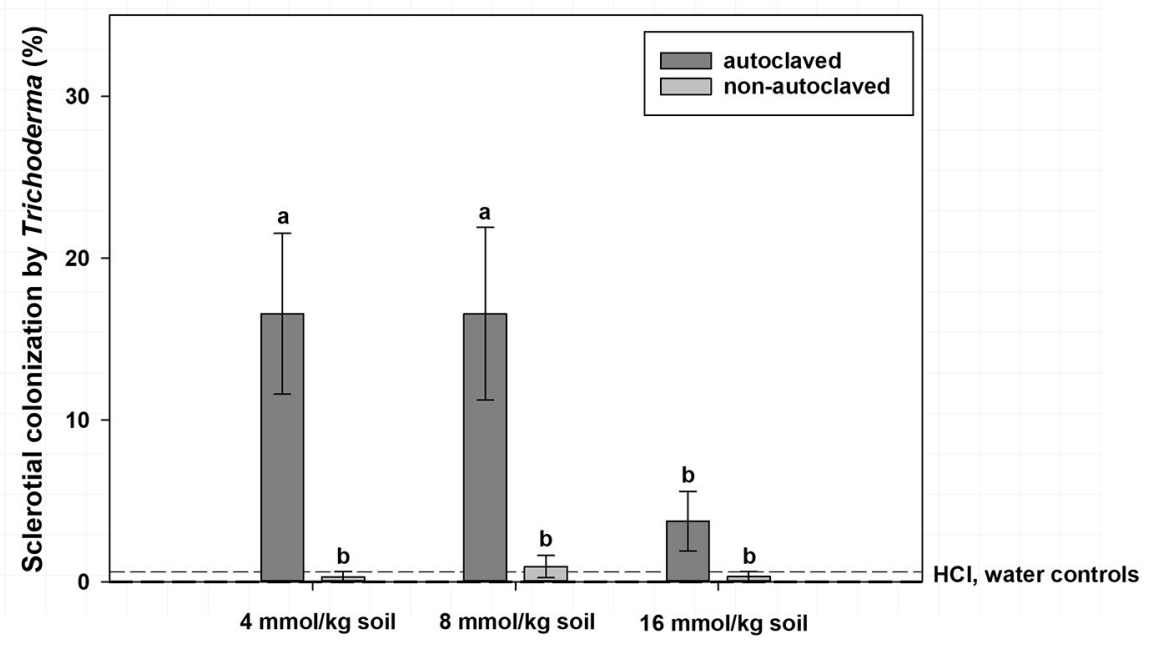

FIGURE 2 | Mean percentage colonization of A. rolfsii sclerotia by Trichoderma spp. in experiment 1 as affected by volatile fatty acid (VFA) concentration and soil autoclaving. Bars indicated by the same letter are not significantly different according to an F-protected LSD at $P \leq 0.05$. Error bars represent standard error of the mean.

colonization by Mucor spp. (7.1 vs. 49.2\%), other fungi (2.4 vs. $12.2 \%)$, and other bacteria ( 0.1 vs. $12.0 \%)$, but increased colonization by Trichoderma spp. (12.3 vs. $0.5 \%)$ and Bacillus spp. (4.1 vs. $0.5 \%$; Table 2 ).

Mean sclerotial colonization by Trichoderma spp. was low $(<1 \%$ colonization) regardless of VFA concentration when soil was not autoclaved and statistically similar to autoclaved soil with the $16 \mathrm{mmol} / \mathrm{kg}$ soil VFA concentration (4\% colonization; Figure 2). This compares to $17 \%$ colonization by Trichoderma spp. for the 4 or $8 \mathrm{mmol} \mathrm{VFA} / \mathrm{kg}$ soil treatments in autoclaved soil. Autoclaved treatments with acetic acid were characterized by the highest colonization by Trichoderma spp., especially at 4 or 8 mmol VFA/kg soil (28 and 33\% mean colonization, respectively;
Figure 3) or autoclaved and ASD soil amendment treatments (34\% colonization, Figure 4 ).

\section{Experiment 2}

In experiment 2, there was a significant main effect of ASD soil amendment $(P=0.02)$, but not VFA (acetic or $n$-butyric) or VFA concentration on populations of Trichoderma (Table 3). For VFA treatments, soil with ASD amendment had a population of 3.4 $\times 10^{6} \mathrm{CFU} / g$ soil whereas soil without ASD amendment had a lower population of $9.6 \times 10^{5} \mathrm{CFU} / \mathrm{g}$ soil. When compared to control treatments, the population of the non-amended $\mathrm{HCl}$ control group was the lowest at $1.6 \times 10^{4} \mathrm{CFU} / \mathrm{g}$ soil, while the controls with no VFA or $\mathrm{HCl}$ had a population similar to 


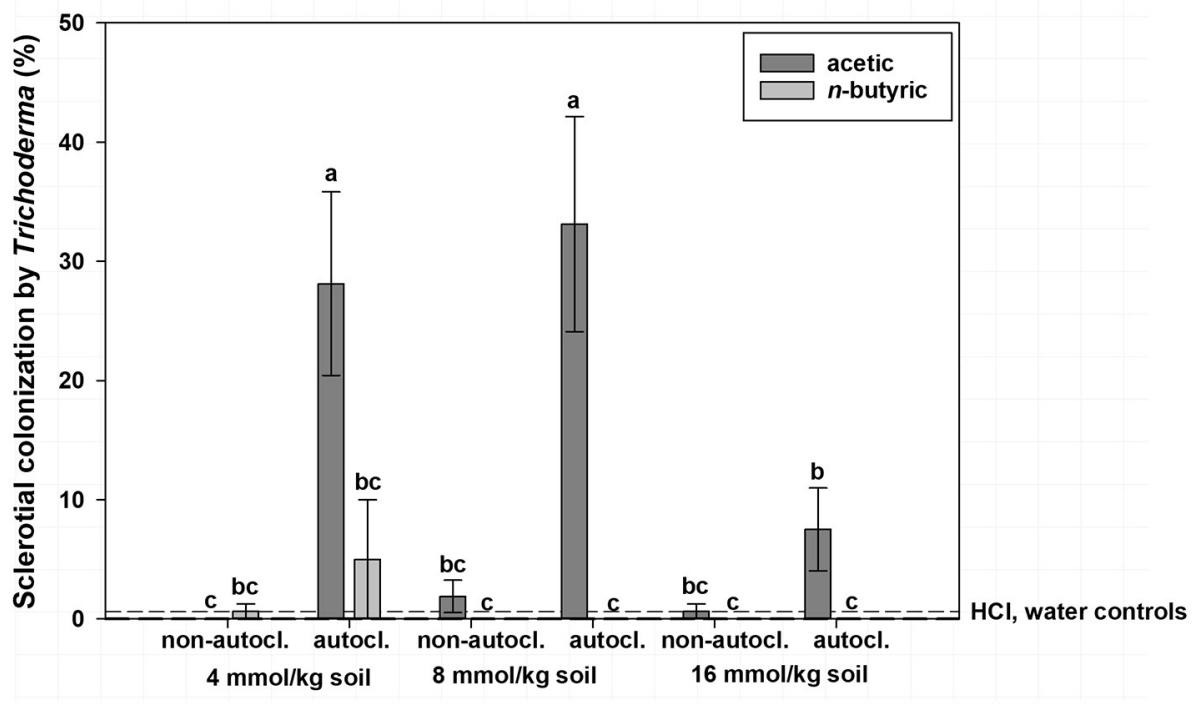

FIGURE 3 | Mean percentage colonization of A. rolfsii sclerotia by Trichoderma spp. in experiment 1 as affected by volatile fatty acid (VFA), VFA concentration and soil autoclaving. Bars indicated by the same letter are not significantly different according to an F-protected LSD at $P \leq 0.05$. Error bars represent standard error of the mean.

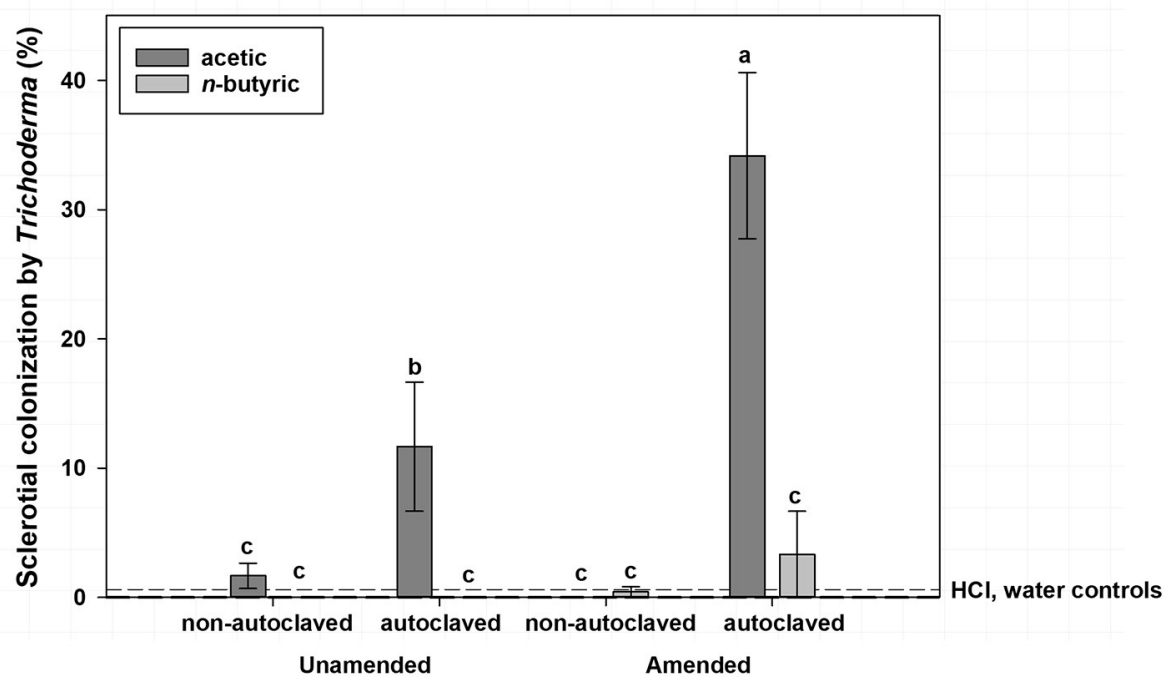

FIGURE 4 | Mean percentage colonization of $A$. rolfsii sclerotia by Trichoderma spp. in experiment 1 as affected by volatile fatty acid (VFA), soil autoclaving, and soil amendment. Bars indicated by the same letter are not significantly different according to an F-protected LSD at $P \leq 0.05$. Error bars represent standard error of the mean.

treatments with VFAs $\left(1.3\right.$ to $1.6 \times 10^{5} \mathrm{CFU} / \mathrm{g}$ soil $)$ regardless of soil amendment.

\section{DISCUSSION}

Our hypotheses were generally supported as related to the effects of VFAs on sclerotial viability as defined by germination post-exposure. While acetic and $n$-butyric acid were significantly different in terms of sclerotial germination, both VFAs significantly reduced sclerotial viability over that of the water and $\mathrm{HCl}$ control treatment groups; the effects increased with increasing VFA concentration in autoclaved soil. Our hypothesis that endemic soil microbial activity would reduce VFA-induced suppression was also supported in that an average of $38.9 \%$ of sclerotia incubated with VFAs in non-autoclaved soil germinated, compared with only $18.1 \%$ germination when incubated in soil that had been sterilized by autoclaving. This suggests that there are processes in biologically active soil that reduce 
TABLE 3 | Analysis of variance for response variables of Trichoderma spp. populations in experiment 2 as affected by the main effects of volatile fatty acid (VFA), VFA concentration, ASD soil amendment, and their interactions.

\begin{tabular}{ll}
\hline & $\boldsymbol{P}$-value \\
\hline VFA & $\mathrm{NS}$ \\
VFA concentration & $\mathrm{NS}$ \\
VFA $\times$ VFA concentration & 0.05 \\
Amendment & 0.02 \\
VFA $\times$ amendment & $\mathrm{NS}$ \\
VFA concentration $\times$ amendment & $\mathrm{NS}$ \\
VFA $\times$ VFA concentration $\times$ amendment & $\mathrm{NS}$ \\
\hline
\end{tabular}

NS, not significant, $P>0.05$.

effectiveness of VFAs against $A$. rolfsii. This is likely because these short-chain organic acids are readily metabolized by aerobic and anaerobic soil microorganisms such as Bacillus and Clostridium (Massie et al., 1985; Coates et al., 1998; Chauhan and Ogram, 2006a,b). Interestingly, although there was a trend of lower sclerotia germination in non-autoclaved soil as VFA concentration increased, percentage germination at $16 \mathrm{mmol} / \mathrm{kg}$ soil was not significantly different than that at $4 \mathrm{mmol} / \mathrm{kg}$ soil. It may be expected that increased soil VFA concentrations could reduce germination percentages in non-autoclaved soils, as in field conditions, but more work is needed to evaluate VFA effects in these conditions.

There was no significant effect of VFA or VFA concentration on soil populations of endemic Trichoderma spp., and treatments with VFAs did not have higher Trichoderma spp. populations than treatments amended with water alone, which did not support our hypothesis. This is also in contrast with that reported by Rosskopf et al. (2014), who reported increased soil Trichoderma spp. when soils in Florida, USA were treated with a blend of organic acids. As the authors did not report the composition of the proprietary mixture used in their study, it is unclear what accounts for the difference between studies, although differences in acid types, concentrations, and soil type could all be expected to play a role. In the present study, the addition of labile ASD amendment to field soil increased Trichoderma spp. populations by more than 300\% over that of the non-amended soil. This population increase under ASD conditions is consistent with other studies involving organic soil amendments (Bulluck and Ristaino, 2002; Kurakov et al., 2008, 2011) and ASD treatment (Shrestha et al., 2018, 2020b). Trichoderma spp. can grow at a reduced rate under anaerobic conditions they are not eliminated by the process and can utilize metabolites produced, such as sugars and alcohols (Bulluck and Ristaino (2002) and Kurakov et al. (2008, 2011). This, in turn, can give Trichoderma spp. an advantage over other soilborne fungi when soil conditions return to aerobic, post ASD treatment.

Acetic acid consistently promoted higher fungal colonization than $n$-butyric acid at both the 8 and $16 \mathrm{mmol} / \mathrm{kg}$ soil concentrations, and was less suppressive to sclerotia of $A$. rolfsii than $n$-butyric acid. Small difference in dissociation of acetic ( $\mathrm{pKa}$ $=4.75$ ) and butyric acids $(\mathrm{pKa}=4.82)$ in the $\mathrm{pH} 5.0$ soil mixtures may have contributed to these findings, but this is unlikely to be the major factor in differences between the VFAs. As a shorter carbon chain fatty acid, acetic acid (a two C compound) is both more readily broken down by microorganisms and is more volatile than butyric acid (a four C compound) and so does not persist as long in soil compared to $n$-butyric acid (Massie et al., 1985; Coates et al., 1998; Chauhan and Ogram, 2006a,b). This indicates that endemic soil microbes may metabolize higher rates of acetic acid more readily than $n$-butyric acid.

This study provides documentation of the direct effects of soil VFA exposure on $A$. rolfsii. This work confirms that the VFAs and the transient strongly acidic soil environment induced by those VFAs characteristic of anaerobic decomposition of organic amendments during soil treatment with ASD contribute to loss of sclerotial viability. Antifungal activity of VFAs is less for acetic compared to $n$-butyric acid and increases in a concentration-dependent manner. The importance of evaluating these mechanisms under realistic field environmental conditions is emphasized by the differences in antifungal VFA activity and by differences in sclerotial colonization in non-sterile soil environments more typical of field conditions than in sterile laboratory conditions. Continued mechanistic evaluations of ASD under realistic field environmental conditions will help to maximize the efficacy of this cultural control against soilborne plant pathogens.

\section{DATA AVAILABILITY STATEMENT}

The raw data supporting the conclusions of this article will be made available by the authors, without undue reservation.

\section{AUTHOR CONTRIBUTIONS}

KS co-designed and conducted all trials, performed related lab work, and wrote the initial draft of the manuscript as a chapter of an M.S. thesis project. US assisted with trial implementation and data collection, assisted with statistical analysis, and critically reviewed the manuscript. BO codesigned all trials, supervised fungal assessments, assisted with data analysis, and critically reviewed the manuscript. KG assisted with data analysis and interpretation and critically reviewed the manuscript. DB co-designed all trials, obtained funding for all trials, supervised trial completion in his lab group, and provided critical revisions to the manuscript draft. All authors contributed to the article and approved the submitted version.

\section{FUNDING}

This study was funded in part by the National Institute of Food and Agriculture, U.S. Department of Agriculture, under Hatch project 1014161, and the USDA-Agricultural Research Service under award A15-0229.

\section{ACKNOWLEDGMENTS}

We thank members of DB and BO labs for their assistance with research studies. 


\section{REFERENCES}

Abbasi, P. A., Lazarovits, G., and Jabaji-Hare, S. (2009). Detection of high concentrations of organic acids in fish emulsion and their role in pathogen or disease suppression. Phytopathology 99, 274-281. doi: 10.1094/PHYTO-99-3-0274

Adams, P. B., and Ayers, W. A. (1979). Ecology of Sclerotinia species. Phytopathology 69, 896-899. doi: 10.1094/Phyto-69-896

Adeleke, R., Nwangburuka, C., and Oboirien, B. (2017). Origins, roles and fate of organic acids in soils: a review. S. Afr. J. Bot. 108, 393-406. doi: 10.1016/j.sajb.2016.09.002

Benítez, T., Rincón, A., Limón, M. C., and Codón, A. C. (2004). Biocontrol mechanisms of Trichoderma strains. Int. Microbiol. 7, 249-260.

Blok, W. J., Lamers, J. G., Termorshuizen, A. J., and Bollen, G. J. (2000). Control of soilborne plant pathogens by incorporating fresh organic amendments followed by tarping. Phytopathology 90, 253-259. doi: 10.1094/PHYTO.2000.90.3.253

Browning, M., Wallace, D. B., Dawson, C., Alm, S. R., and Amador, J. A. (2006). Potential of butyric acid for control of soil-borne fungal pathogens and nematodes affecting strawberries. Soil Biol. Biochem. 38, 401-404. doi: 10.1016/j.soilbio.2005.05.020

Bulluck, L. R., and Ristaino, J. B. (2002). Effect of synthetic and organic soil fertility amendments on southern blight, soil microbial communities, and yield of processing tomatoes. Phytopathology 92, 181-189. doi: 10.1094/PHYTO.2002.92.2.181

Butler, D. M., Kokalis-Burelle, N., Albano, J. P., McCullum, G. T., Muramoto, J., Shennan, C., et al. (2014). Anaerobic soil disinfestation (ASD) combined with soil solarization as a methyl bromide alternative: vegetable crop performance and soil nutrient dynamics. Plant Soil 378, 365-381. doi: $10.1007 /$ s11104-014-2030-z

Chauhan, A., and Ogram, A. (2006a). Fatty acid-oxidizing consortia along a nutrient gradient in the Florida Everglades. Appl. Environ. Microbiol. 72, 2400-2406. doi: 10.1128/AEM.72.4.2400-2406.2006

Chauhan, A., and Ogram, A. (2006b). Phylogeny of acetate-utilizing microorganisms in soils along a nutrient gradient in the Florida everglades. Appl. Environ. Microbiol. 72, 6837-6840. doi: 10.1128/AEM.01 030-06

Chet, I., Harman, G. E., and Baker, R. (1981). Trichoderma hamatum: its hyphal interactions with Rhizoctonia solani and Pythium spp. Microb. Ecol. 7, 29-38. doi: 10.1007/BF02010476

Coates, J. D., Ellis, D. J., Blunt-Harris, E. L., Gaw, C. V., Roden, E. E., and Lovley, D. R. (1998). Recovery of humic-reducing bacteria from a diversity of environments. Appl. Environ. Microbiol. 64, 1504-1509. doi: 10.1128/AEM.64.4.1504-1509.1998

Duffy, B. K., Ownley, B. H., and Weller, D. M. (1997). Soil chemical and physical properties associated with suppression of take-all of wheat by Trichoderma koningii. Phytopathology 87, 1118-1124. doi: 10.1094/PHYTO.1997.87. 11.1118

Gil, S. V., Pastor, S., and March, G. (2009). Quantitative isolation of biocontrol agents Trichoderma spp., Gliocladium spp. and actinomycetes from soil with culture media. Microbiol. Res. 164, 196-205. doi: 10.1016/j.micres.2006. 11.022

Harvey, I. C., Foley, L. M., and Saville, D. J. (1995). Survival and germination of shallow-buried sclerotia of Sclerotinia sclerotiorum in pastures in Canterbury. N. Zeal. J. Agric. Res. 38, 279-284. doi: 10.1080/00288233.1995.95 13127

Hewavitharana, S. S., and Mazzola, M. (2016). Carbon source-dependent effects of anaerobic soil disinfestation on soil microbiome and suppression of Rhizoctonia solani AG-5 and Pratylenchus penetrans. Phytopathology 106, 1015-1028. doi: 10.1094/PHYTO-12-15-0329-R

Hewavitharana, S. S., Ruddell, D., and Mazzola, M. (2015). Carbon sourcedependent antifungal and nematicidal volatiles derived during anaerobic soil disinfestation. Eur. J. Plant Pathol. 140, 39-52. doi: 10.1007/s10658-014$0442-5$

Huang, X., Wen, T., Zhang, J., Meng, L., Zhu, T., and Cai, Z. (2015). Toxic organic acids produced in biological soil disinfestation mainly caused the suppression of Fusarium oxysporum f. sp. cubense. BioControl 60, 113-124. doi: $10.1007 /$ s10526-014-9623-6
Kissel, D. E., Sonon, L., Vendrell, P. F., and Isaac, R. A. (2009). Salt concentration and measurement of soil pH. Commun. Soil Sci. Plant Anal. 40, 179-187. doi: 10.1080/00103620802625377

Kurakov, A. V., Khidirov, K. S., Sadykova, V. S., and Zvyagintsev, D. G. (2011). Anaerobic growth ability and alcohol fermentation activity of microscopic fungi. Appl. Biochem. Microbiol. 47, 169-175. doi: 10.1134/S00036838110 20098

Kurakov, A. V., Lavrent'ev, R. B., Nechitailo, T. Y., Golyshin, P. N., and Zvyagintsev, D. G. (2008). Diversity of facultatively anaerobic microscopic mycelial fungi in soil. Microbiology 77, 90-98. doi: $10.1134 /$ S002626170801013X

Massie, J., Roberts, G., and White, P. J. (1985). Selective isolation of Bacillus sphaericus from soil by use of acetate as the only major source of carbon. Appl. Environ. Microbiol. 49, 1478-1481. doi: 10.1128/aem.49.6.1478-1481.1985

Merriman, P. R. (1976). Survival of sclerotia of Sclerotinia sclerotiorum in soil. Soil Biol. Biochem. 8, 385-389. doi: 10.1016/0038-0717(76)90038-9

Mishra, B. K., Mishra, R. K., Mishra, R. C., Tiwari, A. K., Singh, R. Y., and Dikshit, A. (2011). Biocontrol efficacy of Trichoderma viride isolates against fungal plant pathogens causing disease in Vigna radiata L. Arch. Appl. Sci. Res. 3, 361-369.

Momma, N., Yamamoto, K., Simandi, P., and Shishido, M. (2006). Role of organic acids in the mechanisms of biological soil disinfestation (BSD). J. Gen. Plant Pathol. 72, 247-252. doi: 10.1007/s10327-006-0274-z

Mullen, J. (2001). Southern Blight, Southern Stem Blight, White Mold. The Plant Health Instructor.

Oka, Y. (2010). Mechanisms of nematode suppression by organic soil amendments-A review. Appl. Soil Ecol. 44, 101-115. doi: 10.1016/j.apsoil.2009.11.003

Punja, Z. K. (1985). The biology, ecology, and control of Sclerotium rolfsii. Phytopathology 23, 97-127. doi: 10.1146/annurev.py.23.090185.000525

Rosskopf, E. N., Kokalis-Burelle, N., Hong, J., Butler, D. M., Noling, J. W., He, Z., et al. (2014). Comparison of anaerobic soil disinfestation and drip-applied organic acids for raised-bed specialty crop production in Florida. Acta Horticult. 1044, 221-228. doi: 10.17660/ActaHortic.2014. 1044.26

Rosskopf, E. N., Serrano-Perez, P., Hong, J., Shrestha, U., Rodrigues-Molina, M. C., Martin, K., et al. (2015). Anaerobic soil disinfestation and soilborne pest management. Soil Biol. 46, 277-305. doi: 10.1007/978-3-319-23075-7_13

Runia, W. T., Thoden, T. C., Molendijk, L. P. G., and Berg, W. (2014). Unravelling the mechanism of pathogen inactivation during anaerobic soil disinfestation. Acta Horticult. 1044, 177-193. doi: 10.17660/ActaHortic.2014.1044.21

Sharon, E., Bar-Eyal, M., Chet, I., Herrera-Estrella, A., Kleifeld, O., and Spiegel, Y. (2001). Biological control of the root-knot nematode Meloidogyne javanica by Trichoderma harzianum. Phytopathology 91, 687-693. doi: 10.1094/PHYTO.2001.91.7.687

Shennan, C., Muramoto, J., Lamers, J., Mazzola, M., Rosskopf, E. N., Kokalis-Burelle, N., et al. (2014). Anaerobic soil disinfestation for soil borne disease control in strawberry and vegetable systems: current knowledge and future directions. Acta Horticult. 1044, 165-175. doi: 10.17660/ActaHortic.2014.1044.20

Shinmura, A. (2004). Principle and effect of soil sterilization method by reducing redox potential of soil (in Japanese). Phytopathol. Soc. Japan Soilborne Dis. Workshop Rep. 22, 2-12.

Shrestha, U., Auge, R. M., and Butler, D. M. (2016). A meta-analysis of the impact of anaerobic soil disinfestation on pest suppression and yield of horticultural crops. Front. Plant Sci. 7:1254. doi: 10.3389/fpls.2016.01254

Shrestha, U., Collins, R. L., Swilling, K. J., Ownley, B. H., and Butler, D. M. (2020a). Role of substrate decomposability and volatile fatty acids in anaerobic soil disinfestation activity against Sclerotinia sclerotiorum. Acta Horticult. 1270, 71-82. doi: 10.17660/ActaHortic.2020.1270.8

Shrestha, U., Dee, M. E., Ownley, B. H., and Butler, D. M. (2018). Anaerobic soil disinfestation reduces germination and affects colonization of Sclerotium rolfsii sclerotia. Phytopathology 108, 342-351. doi: 10.1094/PHYTO-04-170152-R

Shrestha, U., Dee, M. E., Piya, S., Ownley, B. H., and Butler, D. M. (2020b). Soil inoculation with Trichoderma asperellum, T. harzianum or Streptomyces griseoviridis prior to anaerobic soil disinfestation (ASD) does not increase ASD efficacy against Sclerotium rolfsii germination. Appl. Soil Ecol. 147:103383. doi: 10.1016/j.apsoil.2019.103383 
Shrestha, U., Ownley, B. H., Bruce, A., Rosskopf, E. N., and Butler, D. M. (2021). Anaerobic soil disinfestation efficacy against Fusarium oxysporum is affected by soil temperature, and amendment type, rate and C: $\mathrm{N}$ ratio. Phytopathology. doi: 10.1094/PHYTO-07-20-0276-R. [Epub ahead of print].

Swilling, K. J., Shrestha, U., Ownley, B. H., Gwinn, K. D., and Butler, D. M. (2021). Volatile fatty acid concentration, soil $\mathrm{pH}$ and soil texture during anaerobic soil conditions affect viability of Athelia (Sclerotium) rolfsii sclerotia. Eur. J. Plant Pathol. doi: 10.1007/s10658-021-02392-8. [Epub ahead of print].

Tenuta, M., Conn, K. L., and Lazarovits, G. (2002). Volatile fatty acids in liquid swine manure can kill microsclerotia of Verticillium dahliae. Phytopathology 5 , 548-552. doi: 10.1094/PHYTO.2002.92.5.548

$\mathrm{Xu}, \mathrm{Z}$. (2008). Overwinter Survival of Sclerotium rolfsii and Sclerotium rolfsii var. Delphinii, Screening Hosta for Resistance to Sclerotium rolfsii var. Delphinii, And Phylogenetic Relationships Among Sclerotium Species. Graduate Dissertation, Iowa State University.

Yedidia, I., Srivasta, A. K., Kapulnik, Y., and Chet, I. (2001). Effect of Trichoderma harzianum on microelement concentration and increased growth of cucumber plants. Plant Soil 235, 235-242. doi: 10.1023/A:1011990013955
Conflict of Interest: The authors declare that the research was conducted in the absence of any commercial or financial relationships that could be construed as a potential conflict of interest.

Publisher's Note: All claims expressed in this article are solely those of the authors and do not necessarily represent those of their affiliated organizations, or those of the publisher, the editors and the reviewers. Any product that may be evaluated in this article, or claim that may be made by its manufacturer, is not guaranteed or endorsed by the publisher.

Copyright $\odot 2021$ Swilling, Shrestha, Ownley, Gwinn and Butler. This is an openaccess article distributed under the terms of the Creative Commons Attribution License (CC BY). The use, distribution or reproduction in other forums is permitted, provided the original author(s) and the copyright owner(s) are credited and that the original publication in this journal is cited, in accordance with accepted academic practice. No use, distribution or reproduction is permitted which does not comply with these terms. 